\section{Grundig om utsnitt av IKT-teknologi}

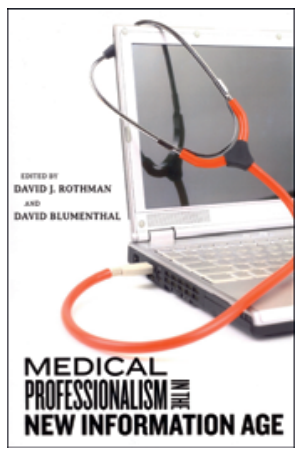

David J. Rothman, David Blumenthal, red. Medical professionalism in the new information age

224 s, tab, ill. Piscataway, NJ: Rutgers University Press, 2010. Pris USD 25

ISBN 978-0-8135-4807-4

Bidragsyterne diskuterer ulike sider ved legers holdninger, bekymringer og forventninger overfor bruk og konsekvenser av informasjonsteknologi i klinisk hverdag. Målgruppen er alle med interesse for medisinsk informasjonsteknologi, selv om deler av utgivelsen retter seg mest mot den som arbeider med IKT til daglig.

Redaktørene har mange års erfaring innen sosialmedisin og indremedisin og sitter i nøkkelposisjoner i viktige fagpolitiske fora i USA. De ulike kapitlene er skrevet av forskjellige forfattere, som bl.a. tar for seg teknologiens påvirkning på regulerende mekanismer for helsemarkedet, historikk bak ulike former for kvalitetsrapportering, pasienters valg av tjenestetilbydere, informasjonsteknologiens juridiske aspekter, kjøp og salg av pasientdata og kontroll av informasjon som fagpolitisk virkemiddel. Avslutningsvis er det en redegjørelse av fremveksten av helseinformatikk som egen profesjon i USA.

Stil og innhold varierer betydelig. Mens introduksjonskapitlene er grundige, men omstendelige, er de senere kapitlene mer lettleste og mindre omfangsrike. Jevnt over holder innholdet et høyt nivå, selv om boken er preget av noter fremfor litteraturreferanser, og det er få illustrasjoner. Det beste kapitlet er ICT and transplantation, som er en meget spennende og til dels skremmende redegjørelse av Internetts betydning for organdonasjon, og da særlig fremveksten av sosiale nettsteder hvor potensielle donorer og mottakere møtes for å avgjøre hvem som skal få organet.

Til tross for at temaene blir grundig behandlet sitter jeg igjen med en følelse av at spørsmålene som er reist i introduksjonen, ikke helt besvares. Jeg finner for eksempel ingenting om konsekvensene av de nye prosesstøttende elektroniske pasientjournalsystemene, hvor legers søkelys rettes mot utforming av kliniske retningslinjer fremfor egenhendig utføring av alle arbeidsoppgaver. Diskusjonen om pasienters økende bidrag til informasjonsgrunnlag og deltakelse i terapibeslutninger er likeledes begrenset til omtale om pasienters søk etter informasjon på Internett og utfordringene dette kan føre til for lege-pasient-forholdet.

Det ville vært bra med flere eksempler og større vilje til å formulere tankene helt ut. Diskusjonen kretser rundt en amerikansk virkelighet som ikke er fremmed for den norske, men som har nok ulikheter til at diskusjonen ikke alltid treffer like godt. Likevel er dette en bok det ikke finnes mange av, og som gir bidrag til en del av litteraturen som for det meste har måttet nøye seg korte tidsskriftartikler.

Jeg vil først og fremst anbefale boken for dem som arbeider med innføring av kliniske IKT-systemer, som deltar i strategiutvikling, eller som ønsker å fordype seg i konsekvensene denne teknologien kan ha for legerollen generelt.

\section{Hallvard Lærum}

Stab IKT

Oslo universitetssykehus

\section{Svindel i amerikansk helsevesen}

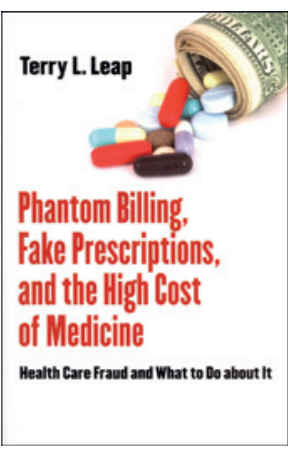

Terry L. Leap

Phantom billing, fake prescriptions, and the high cost of medicine

Health care fraud and what to do about it. 256 s. Ithaca, NY: Cornell University Press, 2011. Pris USD 30

ISBN 978-0-8014-4979-6

Denne boken består av seks kapitler som i hovedsak gir en detaljert oversikt over en mengde ulike eksempler på svindel i det amerikanske helsevesenet. Den krever ingen forkunnskaper, men mangfoldet av oppramsende eksempler og mangelen på analytisk innhold gjør at boken passer best for dem som har både tålmodighet og interesse for temaet.

Hvor stort er problemet med svindel i helsevesenet? Ifølge forfatteren går mellom tre og ti prosent av alle helseutgiftene bort i svindel. Det skulle tilsvare mellom 75 og 200 milliarder dollar hvert år i USA. Slike beregninger er imidlertid så usikre at det grenser til det ubrukelige. Det man kan si med sikkerhet, er at mellom 1990 og 2007 ble det oppdaget over 300 store svindler, og det offentlige fikk tilbake 16 milliarder dollar. Det inkluderer alt fra legemiddelfirmaer som måtte betale fordi de hadde promotert forskrivning av legemidler utenfor godkjent indikasjon (off label), til sykehus som ga skjult betaling til leger for å få flere pasienter.

Eksemplene er mange, og forfatteren sparer ikke på disse. En hudlege skapte sin egen minibank ved å utføre unødvendige inngrep for flere millioner kroner. Et sykehus utførte systematisk utblokkinger til over 50000 kroner per inngrep på pasienter som ikke var kvalifiserte for dette. En leverandør av medisinsk utstyr fikk refundert for levering av dyre hjelpemidler, men leverte billig skrap.

Eksempler er imidlertid ikke nok. De interessante spørsmålene er hva som er årsakene, og hva man kan gjøre med problemet. Forfatteren bruker langt mindre plass på dette. De to hovedanbefalingene er mer informasjon for å skape en bevissthet om problemet og strengere straffer for å avskrekke mulige svindlere.

Anbefalingene er kanskje ikke overraskende - gitt forfatterens påstand om at «A major theme of this book is that the individual perpetrators - not the particular characteristics of a health care system - are the root of fraud and abuse» (s. 180). Med et slikt utgangspunkt blir boken en katalog over eksempler på individers sviktende moral, ikke en analyse av hvordan ulike systemer muliggjør svindel. Er det mindre svindel i systemer der det offentlige styrer, enn i blandingssystemer med offentlig betaling og privat levering av tjenestene? Gir betaling per tjeneste mer svindel enn betaling per person?

Selv om boken er for de tålmodige få, har den også noen gode sider. Detaljert kunnskap om mange tilfeller der store og velrenommerte helsebedrifter har trikset med tall, fører til en sunn skepsis mot offisielle festtaler. Beskrivelsen av de amerikanske lovene gir også ideer til mulige endringer i Norge. For eksempel har USA en lov som beskytter og belønner varslere. Personer som har kjennskap til svindel, kan gå til myndighetene og få en belønning på over $15 \%$ av erstatningsbeløpet. Men de interessante eksemplene er få, og de andre skygger for skogen.

Hans Olav Melberg

Avdeling for helseledelse og helseøkonomi

Universitetet i Oslo 